\title{
DOI:http://dx.doi.org/10.18524/1810-4215.2019.32.182230
}

\section{COMPARISSON OF THE RESULTS OF PROCESSING OF CCD OBSERVATIONS OF SELECTED OPEN CLUSTERS}

\author{
Yu.I. Protsyuk ${ }^{1}$, O.M. Kovalchuk ${ }^{1}$, V.M. Andruk ${ }^{1,2}$ \\ ${ }^{1}$ Research Institute "Mykolaiv Astronomical Observatory", Mykolaiv, Ukraine, \\ yuri@mao.nikolaev.ua \\ ${ }^{2}$ Main Astronomical Observatory NASU, Kyiv, Ukraine
}

\begin{abstract}
Observations of open clusters at the Research Institute "Mykolaiv Astronomical Observatory" (RI MAO) were performed using the KT-50 telescope ( $\mathrm{D}=500 \mathrm{~mm}, \mathrm{~F}=3000 \mathrm{~mm}$ ) in $2011-2018$. As the light receiver, a CCD camera Apogee Alta U9000 (3K x 3K, FOV 42.6' x 42.6') in short drift scan mode was used. In short drift scan mode each observation consisted of several CCD frames with partial overlap in right ascension. All observations were performed using $\mathrm{R}$ light filter. The exposure time was 20 seconds for all frames. All previous astrometric processing was carried out by the Astrometrica program and UCAC4 reference catalog. Using this data we received two catalogs of positions of 4.2 million stars (J2013.6) and 3.3 million starts $(\mathrm{J} 2017.3)$ in the vicinity of open clusters with accuracy (0.03-0.07)". Unfortunately, current version of Astrometrica program have problem with data reduction with Gaia reference catalog in areas with big star density, like vicinity of open clusters near the plane of the Galaxy. At this article, we compared our old results with the new one for several open clusters which carried out with the author's set of programs with primary processing in the MIDAS environment. As reference stars the Tycho2, UCAC4 and Gaia DR2 catalogs were used. The reduction of 548 frames was performed using a polynomial of the third degree. The results obtained by author programs with reference catalogs UCAC4 and Gaia, showed good convergence. Several catalogs of positions of stars up to $17.5^{\mathrm{m}}$ was obtained. The accuracy of the catalogs is $\sigma_{\mathrm{RA}}=0.027$ " and $\sigma_{\mathrm{Dec}}=0.033$ " for Gaia reference catalog and $\sigma_{\mathrm{RA}}=0.032 "$ and $\sigma_{\mathrm{Dec}}=0.036 "$ for UCAC4 reference catalog. At the same time, the accuracy of intraframe processing with the Gaia reference catalog turned out to be near 2 times better than the analogous one with the UCAC4 catalog. The comparison showed the possibility of receiving more good results with Gaia reference catalog.
\end{abstract}

Keywords: Astrometry - Open clusters - Data analysis catalogs

АБСТРАКТ. Спостереження площадок $з$ розсіяними скупченнями в Науково-дослідному інституті «Миколаївська астрономічна обсерваторія» (НДІ MAO) були виконані за допомогою телескопа КТ-50 (D = 500 мм, F = 3000 мм) у $2011-2019$ рр. В якості приймача світла використовувалась ПЗ3-камера Apagee Alta U9000 (3K x 3K, FOV 42,6 'x 42,6') в режимі вкороченого переносу заряду. У режимі вкоро- ченого переносу заряду кожне спостереження складалося 3 декількох ПЗ3-кадрів з частковим перекриттям по прямому піднесенню. Всі спостереження проводилися 3 використанням світлового фільтра R. Час витримки складав 20 секунд для усіх кадрів. Вся попередня астрометрична обробка проводилася програмою Astrometrica в системі опорного каталогу UCAC4. Користуючись цими даними, ми отримали два каталоги положень 4,2 млн зірок $(\mathrm{J} 2013,6)$ та 3,3 млн зірок $(\mathrm{J} 2017,3)$ в площадках навколо розсіяних скупчень 3 точністю $(0,03-0,07) "$. На жаль, поточна версія програми Astrometrica має проблеми з обробкою даних 3 опорним каталогом Gaia у площадках з великою зірковою щільністю, як-от поблизу розсіяних скупчень біля площини Галактики. У цій статті ми порівняли наші старі результати з новими для кількох розсіяних скупчень, які проводилися авторськими програмами 3 первинною обробкою в середовищі MIDAS. В якості опорних зірок використовувались каталоги Тусho2, UCAC4 та Gaia DR2. Редукцію 548 кадрів було виконано за допомогою полінома третього ступеня. Результати, отримані авторськими програмами з опорними каталогами UCAC4 та Gaia, показали хорошу збіжність. Отримано кілька каталогів положень зірок до $17,5^{\mathrm{m}}$. Точність каталогів становить $\sigma \mathrm{RA}=0,027$ " i $\sigma \mathrm{Dec}=0,033 "$ для опорного каталогу Gaia i $\sigma \mathrm{RA}=$ 0,032" i $\sigma \mathrm{Dec}=0,036 "$ для опорного каталогу UCAC4. У той же час, точність внутрішньо кадрової обробки 3 опорним каталогом Gaia виявилася майже в 2 рази кращою, ніж аналогічна 3 каталогом UCAC4. Проведене порівняння показало можливість отримання більш хороших результатів з використанням опорного каталогу Gaia.

Ключові слова: Астрометрія - Розсіяні скупчення Аналіз даних - Каталоги

\section{Introduction}

Observations of open clusters at the Research Institute "Mykolaiv Astronomical Observatory" (RI MAO) were performed using the KT-50 telescope $(\mathrm{D}=500 \mathrm{~mm}, \mathrm{~F}=3000 \mathrm{~mm})$ in $2011-2018$ and were obtained near 35000 CCD frames. As the light receiver, a CCD camera Apogee Alta U9000 (3K x $3 \mathrm{~K}$, FOV 42.6' x 42.6', scale 0.83"/pixel) in short drift scan mode was used (Apogee Alta CCD Camera, 2018). In short drift scan mode each observation consisted of several CCD 
frames with partial overlap in right ascension. All observations were performed using $\mathrm{R}$ light filter. The exposure time was 20 seconds for all frames. For this work we took observations of 7 open clusters (NGC884, NGC1039, NGC1245, NGC1528, NGC1545, NGC2420 and NGC2682) obtained in 2011-2017. All open cluster observed several times in different date. Etch observation have from 4 to $9 \mathrm{CCD}$ frames in depend on declination. Also, all this open clusters were observed in 2018 at the Maidanak Observatory with the Zeiss-1000 telescope (Protsyuk at al., 2018). All previous astrometric processing of our data was carried out by the Astrometrica program (Raab, 2018) and UCAC4 (Zacharias et al., 2013) reference catalog. Using this data we received two catalogs of positions of 4.2 million stars (J2013.6) and 3.3 million starts (J2017.3) in the vicinity of open clusters with accuracy (0.03-0.07)". In this work we repeated data reduction of selected open clusters with the Astrometrica program and Gaia DR2 (Gaia Collaboration, 2018) reference catalogs and the author's set of programs with primary processing in the MIDAS environment (Andruk et al., 2005; 2017; Protsyuk et al., 2014a, 2014b) and different reference catalogs. This software was created to process images that are part of the Ukrainian Virtual Observatory (Vavilova et al., 2012; 2017).

\section{Data reduction}

The reduction of 548 CCD frames was performed using a polynomial of the third degree. As reference stars in our programs the Tycho2, UCAC4 and Gaia DR2 reference catalogs were used. With Astrometrica program we used Gaia DR2 reference catalogs. Unfortunately, current version of Astrometrica program have problem with data reduction with Gaia reference catalog in areas with big star density, like vicinity of open clusters near the plane of the Galaxy. So, for several open clusters we limited magnitude of Gaia catalog to $14.5^{\mathrm{m}}$ or $15.5^{\mathrm{m}}$ in Astrometrica to make reduction (Fig. 1).

The results in scale obtained by author programs with all reference catalogs, showed good convergence (Fig. 2). Integrated star catalog of positions for all plates upto $17.5^{\mathrm{m}}$ was obtained by author's programs. The accuracy of the catalog in UCAC4 system is $\sigma_{\mathrm{RA}}=0.040$ " and $\sigma_{\mathrm{DEC}}=0.046^{\prime \prime}$. The accuracy of the catalog in Gaia system is $\sigma_{\mathrm{RA}}=0.037 "$ and $\sigma_{\mathrm{DEC}}=0.042 "$ (Fig. 3). The accuracy of single observation is shown in Tab. 1. Astrometrica not good yet with Gaia reference catalog in all frames.
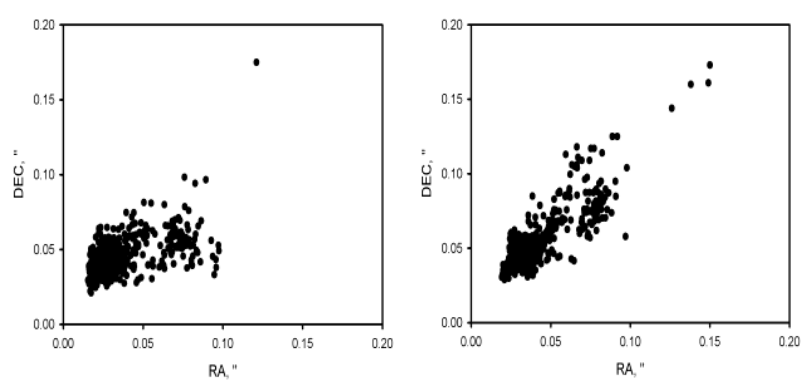

Figure 1: Root mean square (RMS) errors of intra-frame reduction with Gaia limited magnitude 14.5 (left) and 16.5 (right)

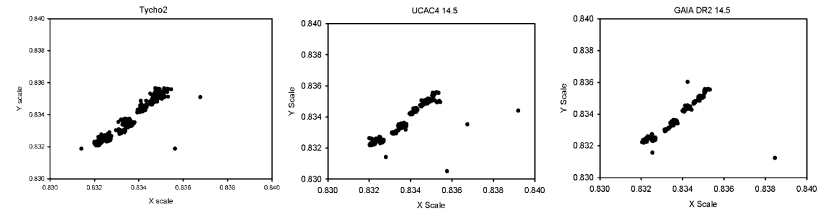

Figure 2: Scale values distribution for all CCD frames depending on the reference catalog Tycho2, UCAC4, Gaia DR2

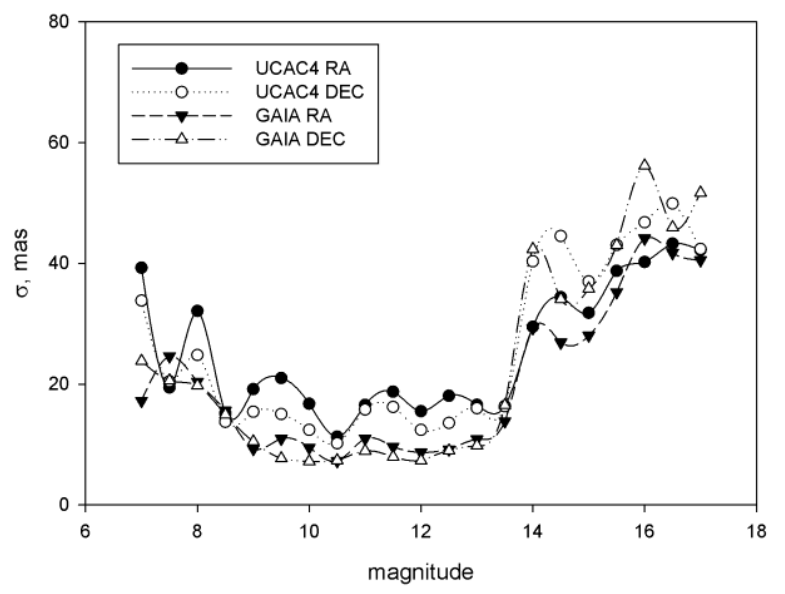

Figure 3: Distribution of our catalogs accuracy from magnitude for reference UCAC4 and Gaia

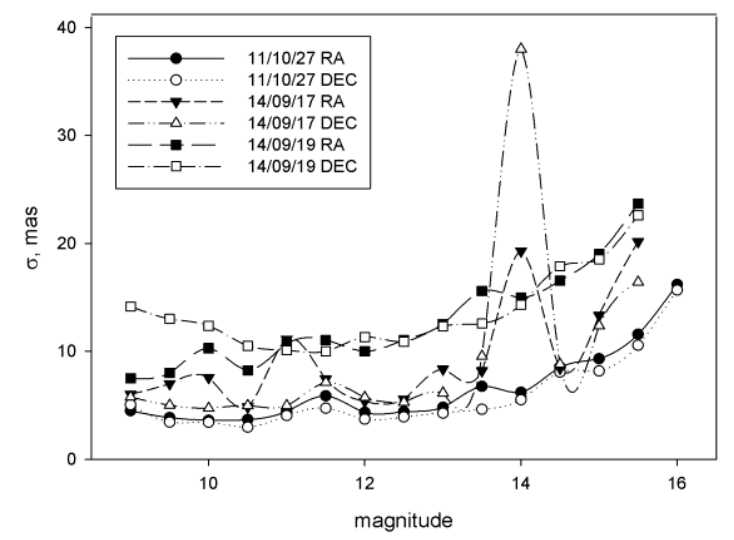

Figure 4: Distribution of inner accuracy in mas for NGC1545, observed in three dates, after processing with reference catalog Gaia DR2

Not so good accuracy near 14 magnitude is explained by some influence from bad columns in CCD matrix in several dates. Weather conditions in different nights also have influence to accuracy. Examples for three dates of NGS1545 observation which reduced with Gaia reference catalog are shown on Figure 4.

At the same time, the inner accuracy of intraframe processing with the Gaia DR2 reference catalog turned out to be 2-3 times better than the analogous one with the UCAC4 catalog. Example for NGC1545 observed at 2011/10/27 shown on Fig.5. Middle RMS for this open cluster at this date is 7 mas for reduction with Gaia and 17 mas with UCAC4. This result obtained from 2000 stars in vicinity of open cluster which were observed approximately 20 times per night. 


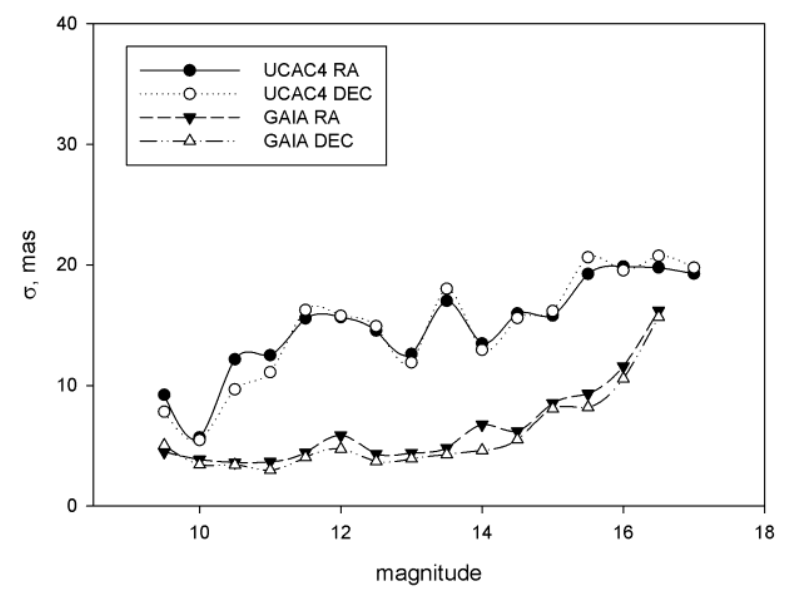

Figure 5. Distribution of RA/DEC inner accuracy in mas of processing of NGC1545 at 2011/10/27 with the reference catalogs UCAC4 and Gaia DR2

Table 1: Comparison of the accuracy of single observation with different software reductions

\begin{tabular}{|c|c|c|c|c|c|}
\hline Software & Ref.cat & $\begin{array}{c}\text { N ref. } \\
\text { stars }\end{array}$ & $\begin{array}{c}\text { N } \\
\text { stars }\end{array}$ & $\begin{array}{c}\text { RA, } \\
\text { mas }\end{array}$ & $\begin{array}{c}\text { DEC, } \\
\text { mas }\end{array}$ \\
\hline Astrometrica & UCAC4 & 28816 & 44157 & 90.5 & 93.5 \\
\hline Astrometrica & Gaia & 11355 & 58202 & 131.8 & 139.2 \\
\hline Author's & UCAC4 & - & 23441 & 82.3 & 91.0 \\
\hline Author's & Gaia & - & 23314 & 71.9 & 84.9 \\
\hline
\end{tabular}

Table 1 show the number of reference stars, number of stars in received catalogs and accuracy of single observation for this catalogs. Astrometrica found more objects but overall accuracy with Gaia catalog worse. Despite the greater accuracy of intraframe processing with Gaia reference catalog (Fig.5) we obtained a slight improvement in the accuracy of the resulting catalogs for the Gaia reference catalog. This is due to the different quality of observations on different nights and a rather significant random error.

\section{Conclusion}

The processing of observations with new reference catalog GaiaDR2 gives significantly better results with our software. To further improve the result, we need to prefilter images before processing in MIDAS software. The high accuracy of intraframe processing with the Gaia reference catalog shows great potential for further improving the accuracy of our catalogs.

\section{References}

Andruk V.M., Pakuliak L.K., Golovnia V.V. et al.: 2017, Scince and Innovation, 13(1), 17.

Andruk V.M., Vidmachenko A.P., Ivashchenko Yu.M.: 2005, Kinem. Phys. Cel. Bodies., Suppl. 5, 544.

Apogee Alta CCD Camera, [online] Available at: (https://optcorp.com/products/apogee-alta-f9000-d07monochrome-ccd-camera).

Gaia Collaboration: 2018, $A \& A$, 616, A14.

Protsyuk Yu.I., Martynov M.V., Mazhaev A.E. et al.: 2014, Kinem. Phys. Cel. Bodies., 30, N6, 296.

Protsyuk Yu.I., Andruk V.M., Kazantseva L.V.: 2014, Odessa Astron. Publ., 27, 59.

Protsyuk Yu. I., Shukhratov Sh. Sh., Kovalchuk O. M. et al.: 2018, Odessa Astron. Publ., 31, 231.

Raab H., Astrometrica, [online] Available at: (http://www.astrometrica.at/).

Relke E., Protsyuk Yu.I., Andruk V.M.: 2015, Odessa Astron. Publ., 28, 211.

Vavilova I.B., Pakulyak L.K., Shlyapnikov A.A. et al.: 2012, Kinem. Phys. Cel. Bodies, 28, N4, 85.

Vavilova I.B., Yatskiv Ya.S., Pakuliak L.K. et al: 2017, IAUS, 325, 36.

Zacharias N., Finch C.T., Girard T.M. et al.: 2013, Astron. J. 145, 44. 